\title{
Teacher Professional Competency Analysis: Implementation Aspect of Continuous Professional Development (CPD)
}

\author{
Annisa Vidya Safitri \\ Sutrisno \\ Program Studi Pendidikan Tata Niaga Universitas Negeri Malang \\ Email: sutrisno.fe@um.ac.id
}

\begin{abstract}
The purpose of this study was to identify the practice of teacher reflection as the basis for the implementation of Sustainable Professionalism (PKB) program based on Permendiknas No. 16/2007 at SMKN 2 Kediri. This research is qualitative with phenomenology design. The informants of this research are principal, productive teacher of marketing, vice principal, teacher and marketing teacher. Technique of data collecting done by in-depth interview and documentation. The validity of the data using technique triangulation and source. Data analysis using Miles and Huberman interactive models, extension of observation, and referential adequacy. The results showed that the reflection was not used as the basis of CLA and the teachers did not implement the CLA planning. Elements of PKB activities have been in accordance with the guidelines of selfdevelopment and scientific publications. PKB activities have an impact on teacher groups that discuss research issues, more varied and contextual KBM, and administrative demands for teachers.
\end{abstract}

Keyword: Teacher professional competency, continuous professional development (CPD), reflective practice.

Making of Regulation No. 14 in 2015 about Teacher and Lecture and government regulation No. 19 in 2005 about National Education Standard, basically are government commitments for regulate and improving education quality. Improvement of teacher competency need surveillance and evaluation, so it makes reliable and directed result (Ilanlou \& Zand, 2011; Ramdhani et al., 2012). Based on National Education Ministry Regulation (Permendiknas) No. 35 in 2010 article 4, start from 1 January 2013, government apply Teacher Performance Assessment Program (TPA). The result of TPA used for collect information about teacher capability in order to apply their competency and skill in studies. Further utilization of after-TPA performance profile (Teacher Performance Assessment) is made Continuous Professional Development (CPD) activity which include selfdevelopment, science publication, and innovative creation. Government through those professionalism assessment and mapping will create teacher who have competency and wealth, so they can increase overall education quality.

Implementation of profession development program for teacher still didn't have pattern which is fit with its meaning and objective. Based on research result, that there are several constrain in continuous profession development activity 
(Wuryandari, 2014:117; Heldenhuys \& Oosthuizen, 2015) are 1) insufficient of teacher information about CPD program which held by government, 2) teacher assignment which not continuous so teacher get partially comprehension, 3) lack of teacher prepare and commitment in order to following CPD activity. 4) reluctance of teacher to fully contribute in CPD activity, 5) CPD activity not followed by all teacher, 6) teacher compares financial consequence of CPD activity with teacher certification in position, so it will impact to decrease motivation of contribution in CPD activity. 7) training and workshop method that didn't impact enough for teacher professionalism improvement. Because of those condition, Education and Culture Ministry will focus to identify teacher weakness, so treatment or regulation that made will give progressive impact to future teacher enhancement. (Anam, 2089: 117).

In held of Alfamart and Axioo industry class program in SMKN 2 Kediri give academic consequence for teacher also students. Studies that held by teacher have to supported student competency, so in line with global industry standard as graduate candidate user. To fulfill those demand, teacher have to had competency that sophisticate and actively teach students. (Kangas et al., 2017; Sibley et al., 2017; Comi et al., 2017). Because of those condition, it needs implementation of directed development program that corresponding with government guideline.

Improving teacher professionalism need to be supported by school party so that will create synergy between party. Supports for facility equipment, administrative services, financial support, direction, motivation, also other convenience that supplied for motivating teacher in order to improving their competence (Nasongkhla \& Sujiva, 2015; Kanokorn, Pongtron \& Somjai, 2012; Plessis, 2015; Leijen et al., 2015). Improvement of productive marketing teacher competency has been done in SMKN 2 Kediri sustainably. Based on interview result with productive marketing teacher, teacher professional activity done routine and followed by all marketing teacher individually also group. Start from implementation of MGMP program, seminar, workshop, training, industry visitation, on the job training, guest lecture, also other teacher academic activity cooperates with related party like Development and Teacher Empowerment and Teaching Force Center (P4TK) and business practice coach also implement class action research for several teachers. Those activities used for preparing teacher in following years so they capable to work professionally (Kanokorn, Pongtron \& Sujanya, 2014). Next, teacher competency improving program result followed up through impacting method in MGMP meeting that involved all productive marketing teachers.

This research focusing to productive marketing teacher professional competency in SMKN 2 Kediri that implement continuous professional development (CPD) based on teacher reflection action. Data or information which used in this research directed for knowing teacher reflection action practice, CPD program mechanism, and impact of CPD activity for teacher.

Based on preliminary research result to productive marketing teacher in SMKN 2 Kediri finds that learning reflection activity which done by teacher and contribution from several party, includes assessors and principles as supervisor and student as users, also teacher himself. But practically, reflection result not use as foundation of teacher professionalism development activity planning. Fact in 
the field also revealing that there isn't demand for teacher to do reflection action intensively. Those research findings opposite with Arifin's opinion (2011: 229) which state that teacher need to do reflection toward self-performance constantly in order to building quality of thinking behavior pattern as teacher. Reflection not only for self-identification, but also have to followed up in order to professional improving. Which is state in Impedovo's and Malik's research $(2016: 100)$ that core value of reflection action is doing self-improvement continuously through critical investigation in practice of class learning, making assessment, and changing learning behavior. Through self-reflection, teacher able to assess learning that done in class, so can be developed for next activity (Rhoads \& Weber, 2016)

Reflection action practice gives positive impact to development teacher professionalism. Reflection function also supported by Korthagen's research result (2014: 74) which revealing core of teacher reflection is in teacher awareness level toward essential of a problem in learning. This awareness for identification problem in learning able to achieve through reflection practice that involved thinking dimension, emotional, need, and behavior. Sometimes many teachers stuck in try and error activity instead reflective thinking in their class environment management, so it causes class environment that random, unpredicted, and less student learning (Cruickshank, 2014: 238). Truthfully, reflection action function as manifest of teacher performance assessment need to review further so gets imagine of professional competency standard that had to do by teacher.

Planning and implementation of Continuous Professionalism Development program (CPD), which is consider to teacher reflection result, able to lead the program become more effective and more impact to teacher competency continuously (Berg, Ros \& Beijaard, 2015). Hopefully, through this teacher competency analysis research, able to know teacher performance profile based on demand of national education standard that regulate in Education and Culture Ministry Regulation. So, research result able to take advantage as baseline of evaluation and refinement CPD implementation.

Hopefully, this research can give positive contribution for SMKN 2 Kediri, Education Services of Kediri City, and other researcher as reference for implementation analysis of Teacher Professionalism Development through CPD policy.

\section{METHOD}

This research is qualitative research with phenomenology design. Contribution of researchers in field is key instrument for success of research. Place for research at SMKN 2 Kediri. Key informants are principal and productive marketing teacher. For supportive informants are vice principal in curriculum field, productive marketing teacher assessors, and XII grade marketing class and X grade Alfamart Program students. Research procedure for collecting data using in-depth interview and documentation study. Analysis that will be applied are data reduction, data presenting, and data verification. Validating method that will be used in this research are triangulation technique and source, reference sufficiency, extended observation. 


\title{
RESULT \& DISSCUSSION
}

\begin{abstract}
Result

\section{Self-Reflective Activity Practice}

Productive marketing teacher have done reflection action with involving self and other. This thing able to look from several implementation indicators of reflective action that done by teacher. Research in field finds proves that teacher awareness in order to do reflection to improve learning. Teacher realize that need to implemented competency improvement continuously, especially in IT field and indepth subject matter for supporting teacher profession task. Reflective activity can use certain document that able to represent teacher performance. Fact in the field shows that teacher have self-reflective document, which is: 1) learning journal, 2) TPA result document, 3) EPT (Employee Performance Target), and 4) student's study result. But not all teacher aware and use those documents as foundation to know teacher performance. Implementation of CPD activity based on reflective and teacher performance assessment result which done previously with assessor contribution. Just like found in the field that Teacher Performance Assessment (TPA) activity implemented 2 (two) times, which is TPA Formative and Summative. The weakness is subjectivity assessment so probably there is assessment that not representative enough. This thing can overcome with assessor and teacher awareness in order to implement TPA just like guideline and instrument from government. Main foundation that used by productive marketing teacher as reflective foundation is result/score of student learning. If there is student score that below KKM productive marketing (SKM 70.00), it means that teacher need to implement reflection. Reflective material includes teaching method, learning approach, difficulty of student learning, material syntax, and difficulty level of test question.
\end{abstract}

\section{Planning, Implementation, and Further Action CPD Activity Which Done by SMKN 2 Kediri Productive Marketing Teacher}

Productive marketing teacher have understood policy about teacher professionalism through socialization activity which done by Education Services Kediri City. But teacher not yet understand implementation practice of those policy in teacher professionalism development context, so in every stage of CPD Activity (Continuous Professional Development), we can find differences with guideline of CPD implementation by Education and Culture Ministry.

CPD activity planning not implemented individually by teacher. CPD activity that will be done by teacher adjusted with schedule which have determined by school based on recommendation of activity organizer. Kind of CPD activity that followed by productive marketing teacher has been fulfilled substances which determine by Education and Cultural Ministry in CPD guideline, is fulfill selfdevelopment and scientific publication substances. Example, in 2016 all productive marketing teacher actively join several self-development activities, such as training for teacher (TFT), on the job training, seminar, guest lecture, and study excursion about improving teacher soft skill in modern marketing field. After following CPD activity, then doing follow up result through impacting method which done by 
teacher to other teacher and Learning Activity in class with students. Evidence of CPD activity portfolio which done by teacher in certificate form used as foundation of assessment for purpose credit score which written in Employee Performance Target (EPT) documents.

\section{Impact of Post-Implementation CPD Development Activity for SMKN 2 Kediri Productive Marketing Teacher}

CPD implementation gives impact increasing administrative demand for teacher. CPD activity substance which done by productive marketing teacher through selfdevelopment and scientific publication gives impact to learning activity in class. Teacher use CPD activity result as variation of study materials and actual examples about material application in real life, so productive marketing study become more contextual. CPD activity probably done collectively with other teachers. This thing impacting to increase networking or peer group for teacher as knowledge sharing and information facilities about research also certain achievement so supporting each other.

\section{Discussion}

\section{Practice of reflective action or self-evaluation which done by SMKN 2 Kediri productive marketing teacher}

One of core competency in professional competency for teacher is doing continuous professional development (CPD) activity through reflective action. This competency also includes into 14 (fourteen) competency that shows teacher performance as implementation foundation of teacher performance assessment (TPA). One of those indicator is teacher able to do self-evaluation specifically, complete, and supported by learning proses assessment result as proof of their performance (Sellars, 2012). Just like what have done by productive marketing teacher in SMKN 2 Kediri which realize that need to do improving teacher competency continuously. But reflection not yet understood by teacher as routine needs related to their performance feedback. This thing caused by limited time and teacher energy in order to do supportive task of teacher profession beside learning activities

Arifin (2011: 29), aspect that need to be reflected by teacher include selfmotivation, theory, and learning model, learning facility, learning implementation in class, also self-quality development. Facilities that used as foundation to reflecting those aspects is teacher performance assessment result document, which done by teacher, principal, also assessor (Russo \& Wilsey, 2014; Mogonea, 2015; Trif \& Popescu, 2013; Killeavy \& Moloney, 2010). Just like what have done by productive marketing teacher in SMKN 2 Kediri that reflective action or selfevaluation able to do primary from student study result (Buddin \& Zamarro, 2009). Measurement of student's learning achievement result based on MCC (Minimum Completeness Criteria) productive marketing is 70,00. Things that reflected by teacher about learning material, learning method, teacher presentation, question difficulty, and difficulty of study that experienced by students while learning process (Louws et al., 2017). Further action that gave to student is teacher doing remedial for students that their score below MCC and 
enrichment for students that their score above MCC to increasing score and student comprehension (Chen, 2011; Lin, Wu\& Hsueh, 2014; Frisancho et al., 2016; Crooks, 2011; Wiliam, 2011).

Reflective activity which based on student study result evaluation can give positive impact toward refinement which done by teacher to next learning (Rhoads \& Webber, 2016; Nevgi \& Löfström, 2015; Sööt \& Viskus, 2015; LaBoskey, 2010; Rauduvaitè, Lasauskienè \& Barkauskaitė, 2015; Pleschová \& McAlpine, 2016; González \& Deal, 2017). But reflection toward study result evaluation cannot become the only source in order to do reflective their performance. Those things caused by teacher's repressive follow up action, it means that teacher do reflection when there is happened class learning problem in class (Rosenbluh, 2016; Hagevik, Aydeniz \& Rowell, 2012). If there isn't learning problem happened, teacher will think there isn't problem in teacher learning method also students. Appealing of those weakness, it means that thescre reflection not only based on student study result evaluation (Hagevik, Aydeniz \& Rowell, 2012). Teacher will be easy to justify teaching successfulness which done with ignoring other factor which cause learning successfulness (Buddin \& Zamarro, 2009).

There are several documents which able to used as foundation of teacher reflective action are learning journal, employee performance target documents, critics and suggestion from students, also teacher performance profile in TPA report (Teacher Performance Assessment. Based on research in-field result found that productive marketing teacher actually have those documents, but still not used maximally as implementation foundation of performance reflection, impact of reflective implementation that not yet maximal is follow up of reflection result that not yet directed just like teacher professionalism development guideline from Education and Culture Ministry. Based on CPD guideline book which launched by Education and Culture ministry in 2012 state that reflection or teacher selfevaluation result is foundation to implement teacher performance assessment and follow up of increasing competency also teacher professionalism continuously (Sellars, 2012). Because of that condition, if the main foundation didn't implement maximally, it will cause TPA and CPD activity become less effective. So, it can be concluded that practice of reflective action which done by productive marketing teacher in SMKN 2 Kediri have been done, but not yet using self-reflective document source maximally. Reflective not yet understand as teacher routine needs because there are several tasks beside teaching in class which using much time and energy. Reflection also not yet understand as foundation of teacher TPA and CPD implementation.

\section{Planning, implementation, and Follow Up CPD Activity Which Done by SMKN 2 Kediri Productive Marketing Teacher}

Improving of teacher professionalism through CPD is government policy that start in 2013 as manifestation of National Education Ministry regulation. Before it has done completely, need to do socialization about CPD implementation and execution in field. Based on interview result with productive marketing teacher in SMKN 2 Kediri knows CPD policy at first time from socialization which done by MGMP Productive Marketing with presenter from Kediri City Education Services. Some of teacher said that that socialization not yet done effectively because until 
now teacher practice about implementation of CPD policy still comprehend partially. Those things proved with not yet understood relation between selfreflection, TPA, and CPD as development mechanism of teacher professionalism development continuously (Wuryandini, 2014). New policy in education cannot implement just like that. It need policy socialization which done intensively also with implementation role mode, so there aren't differences between policy guideline and implementation in filed (Koenen, Dochy \& Berghmans, 2015). Availability of role mode also can accommodate variative field condition, so policy and program able to be done independently but still in line with guideline. Implementation of policy socialization which didn't do intensively will cause differences of policy implementation, so cannot achieve objective which have set (Wuryadini, 2014). Implementation differences of CPD policy also happened in practice which done by productive marketing teacher in SMKN 2 Kediri.

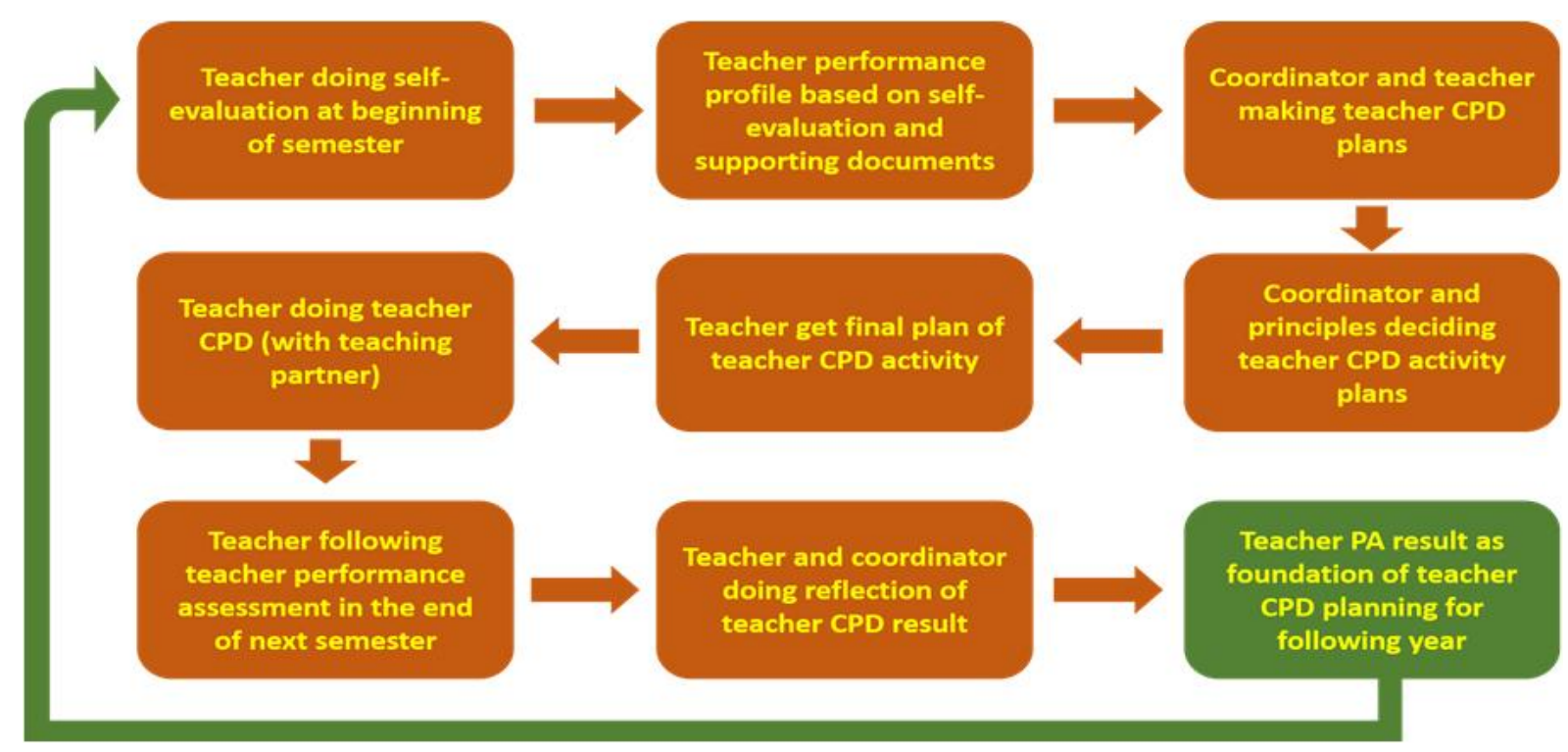

Figure 1.1 Mechanism of Continuous Professional Development Source: Buku Pedoman dan Pengelolaan PKB Kemendikbud, 2012: 35

Based on those figures of CPD implementation stage knew that foundation of CPD activity planning is teacher performance profile which made after teacher do self-reflection and formative TPA activity. CPD planning involve CPD coordinator and teacher in order to make it until CPD planning finalization stage by principal. After did CPD by teacher, then will be followed up with summative TPA to scoring competency improvement also teacher professionalism after follow CPD. This reflection result of summative TPA become foundation of teacher CPD planning following years. This thing called as professional development which done continuously (Evans et al., 2017).

But practically, CPD planning didn't completely do by teacher. CPD activity that followed by teacher based on availability of organizer schedule, private also national services based on recommendation from school. So, teacher didn't do CPD 
activity planning individually because all activity done like school announcement. It can be concluded that planning which done by productive marketing teacher didn't yet do just like CPD implementation guideline.

CPD activity have to fulfill teacher profession development substance which regulated by PermennegPAN and RB No. 16 2009, which is self-development, scientific publication, and innovative creation. Implementation CPD activity that followed by productive marketing teacher in SMKN 2 Kediri, since application of COD policy until 2016, most of activity is self-development activity are training, seminar, guest lecture, workshop that organized by authority or industry, also active in MGMP activity. Self-development activity which done by productive marketing teacher also related with industry class program which organized by SMKN 2 Kediri incorporate with PT. Sumner Alfaria Trijaya. So, several selfdevelopment activities involving field coach which in Alfamart Class program. While scientific publication and innovative creation substance only done by productive marketing teacher which have last predicate IV/a and IV/b.

Follow up action which done by productive marketing teacher after doing CPD activity is impacting activity result to other teacher and use it for learning material in class. Impacting done through material presentation of CPD activity result in learning activity in class. Through those impacting activity, students know theory application in real world, so supporting student metacognitive ability and learning process become more contextual (Gonzalez \& Deal, 2017). Impacting activity also done to other productive marketing teacher through sharing in MGMP forum. But, its executions don't intensive because importance of each teacher which different. Whereas, follow up of CPD in summative TPA implementation didn't do by teacher just like guideline, because there isn't differences implementation practice with formative TPA. So, it can be concluded that CPD follow up which done by teacher is done impacting to other teacher through MGMP and used for learning refinement which done in class. So, follow up which done by teacher is good enough, but didn't yet completely in line with COD guideline.

\section{Impact of post-implementation CPD activity towards productive marketing SMKN 2 Kediri teacher}

Impact of continuous professional development (CPD) post-implementation for teacher is increasing teacher administrative demand in order to creating portfolio. Through increasing of administrative demand for teacher, also will impact to discipline in order to do their task as certified teaching forces. CPD activities result in self-development form bring impact to increase teacher competency and subject matter knowledge which more sophisticate, so able to support learning which is better quality through material variation that not only theory but also applicative (Korthagen, Loughran \& Russel, 2006)

Next, impact that resulted from post-CPD activity by teacher, there is increasing teacher knowledge and understanding to make scientific creation also innovative creation to improving learning in class (Evans et al., 2017). Basically, teacher profession not only does their task in teaching. But, to develop teacher profession also demanding as researcher through creating PTK also innovative creation to improve learning quality. Just like done by several productive marketing teachers that use CPD activity to adding network as knowledge and 
information sharing facilities about research also certain achievement so supporting each other (Jiraro, Sujiva \& Wongwanich, 2014). But, teacher awareness in order to make scientific creation also innovative creation still low. This thing caused by many administrative demand and teacher task besides teaching which use much energy and time, so creating learning scientific creation also innovative creation claimed as workload for teachers.

\section{CONCLUSION \& SUGGESTION}

\section{Conclusions}

Based on research finding and discussion, researcher can take conclusion toward implementation aspect of CPD activity through reflection action to productive marketing teacher in SMKN 2 Kediri. Truthfully, practice of reflection action or self-evaluation has been done by teacher. Foundation of main reflection is from student study result. But, reflection not yet applied like CPD guideline and not used as foundation of CPD activity implementation. In the reality also find some differences about CPD steps relevance with guideline that issued by Education and Culture Ministry. Plan of CPD activity didn't implement by teacher because activity fitted to organizer schedule availability of authority and private also. Other indication isn't contribution from principles also assessor as teacher performance assessor in order to plan kind of CPD activity that will be implemented by teacher like their performance profile. Implementation of CPD activity that followed by teacher had fulfill substance of CPD activity in line with guidelines are selfdevelopment and scientific publication. Self-development activity which done by teacher are seminar, workshop, training course cooperate with field coach from PT. Sumber Alfaria Trijaya, guest lecture and active in to MGMP activity. But productive marketing management awareness in order to fulfill scientific publication substance also innovative creation still low. Teachers knows that doing research and make study innovation creation not yet become a need. Advance action post-implementation of teacher that attend COD activity is good enough through impacting CPD result. Those impacting done for other teacher through MGMP sharing activity.

CPD activity result also can be used by productive marketing teacher for study in class refining through giving study material variation. Impact of CPD implementation for productive marketing teacher in SMKN 2 Kediri is make more teacher administrative demand in order to make self-portfolio. Through increasing of administration demand for teacher, also give impact to discipline in order to do their task as certified teaching force. CPD activity also giving positive impact to teaching which did by teacher in class trough impacting process. This thing support study that better quality and contextual. CPD activity also can be used by productive marketing teacher as place for knowledge and information sharing about certain research and achievement. 


\section{Suggestions}

Based on research conclusion, researcher give suggestion to party who related with implementation of teacher's CPD policy. First for Authority of Education in Kediri, that this research able to use as baseline to do monitoring and implementation evaluation of CPD in school to determine improving implementation so it will correspond with Education and Culture Ministry's CPD guidelines. Second for SMKN 2 Kediri productive marketing teacher, that this research able to use as baseline to increasing teacher awareness and discipline in order to take advantage self-reflection source. Besides, able to use as baseline to evaluate action of teacher self-reflection, so will use to determine implementation of TPA and CPD. Refinement of implementation CPD planning step and fulfill innovative creation factor needs to increase by teachers, so the purpose of teacher professionalism development program can be achieved. Third for further research, able to use as reference for further research in teacher competency and professionalism analysis but different scope and background.

\section{REFERENCES}

Anam, S. 2009. Pergumulan dalam meningkatkan mutu pendidik dan tenaga kependidikan (2007-2009). Jakarta: Mahamedia Cipta Caraka.

Arifin. 2011. Kompetensi Guru dan Strategi Pengembangannya. Yogyakarta: Lilin.

Barak, L.0. \& Yinon, H. 2007. When theory meets practice: What student teachers learn from guided reflection on their own classroom discourse. Teaching and Teacher Education, (Online), 23: 957-969, (http://www.sciencedirect.com), diakses 11 Mei 2017.

Barnawi dan Arifin, M. 2014. Pengembangan Keprofesionalan Berkelanjutan Bagi Guru. Yogyakarta: Gava Media.

Bergh, L.v.d., Ros, A., Beijaard, D. 2015. Teacher learning in the context of a continuing professional development programme: A case study. Teaching and Teacher Education, (Online), 47: 142-150, (http://www.sciencedirect.com), diakses 11 Mei 2017.

Chen, L.H. 2011. Enhancement of student learning performance using personalized diagnosis and remedial learning system. Computers \& Education, (Online), 56 (1): 289-299, (http://www.sciencedirect.com), diakses 12 Mei 2017.

Crooks, T. 2011. Assessment for learning in the accountability era: New Zealand. Studies in Educational Evaluation, (Online), 37 (1): 71-77, (http://www.sciencedirect.com), diakses 12 Mei 2017.

Cruickshank, D. R., Jenkins D. B., dan Metcalf, K.K. 2014. Perilaku Mengajar The Act of Teaching. Jakarta: Salemba Empat. 
Dudley, P. 2013. Teacher learning in Lesson Study: What interaction-level discourse analysis revealed about how teachers utilised imagination, tacit knowledge of teaching and fresh evidence of pupils learning, to develop practice knowledge and so enhance their pupils' learning. Teaching and Teacher Education, (Online), 34: 107-121, (http://www.sciencedirect.com), diakses 12 Mei 2017.

Evans, N.S, Steven son, R.B., Lasen, M., Ferreira, J.A. \& Davis, J. 2017. Approaches to embedding sustainability in teacher education: A synthesis of the literature. Teaching and Teacher Education, (Online), 63:405-417, (http://www.sciencedirect.com), diakses 13 Mei 2017.

Frisancho, V., Krishna, K., Lychagin, S.,Yavas, C. 2016. Better luck next time: Learning through retaking. Journal of Economic Behavior \& Organization, (Online), 125: 120-135, (http://www.sciencedirect.com), diakses 12 Mei 2017.

González, G. \& Deal, J.T. 2017. Using a Creativity Framework to Promote Teacher Learning in Lesson Study. Thinking Skills and Creativity, (Online), (http://www.science direct.com), diakses 13 Mei 2017.

González, K., Padilla, J.E., Rincón, D.A. 2011. Roles, Functions and Necessary Competences for Teachers' Assessment in b-Learning Contexts. Social and Behavioral Sciences, (Online), 29: 149-157, (http://www.sciencedirect.com), diakses 10 Mei 2017.

Hagevik, R., Aydeniz, M., Rowell, C.G. 2012. Using action research in middle level teacher education to evaluate and deepen reflective practice. Teaching and Teacher Education, (Online), 28 (5): 675-684, (http://www.sciencedirect.com), diakses 12 Mei 2017.

Ilanlou, M. \& Zand, M. 2011. Professional Competencies of Teachers and the Qualitative Evaluation. Social and Behavioral Sciences, (Online), 29: 11431150, (http://www.sciencedirect.com), diakses 10 Mei 2017.

Impedovo, M. A. \& Malik, S.K. 2016. Becoming A Reflective In-Service Teacher: Role of Research Attitude. Australian Journal of Teacher Education, (Online), 41 (1): 100-112. (htt://dx.doi.org /10.14221/ajte. 2016 v41n1.6), diakses 7 Oktober 2016.

International Encyclopedia of Education (Third Edition). (Online), 391-396, (http://www.sciencedirect.com), diakses 11 Mei 2017.

Jiraro, S., Sujiva, S., Wongwanich, S. 2014. An Application of Action Research for Teacher Empowerment to Develop Teachers' Test Construction Competency Development Models. Social and Behavioral Sciences, (Online), 116: 1263-1267, (http://www.sciencedirect.com), diakses 12 Mei 2017. 
Kangas, M., Siklander, P., Randolph, J., Ruokamo, H. 2017. Teachers' engagement and students' satisfaction with a playful learning environment. Teaching and Teacher Education, (Online), 63: 274-284, (http://www.sciencedirect.com), diakses 11 Mei 2017.

Kanokorn, S., Pongtorn, P., Somjai, M. 2012. Teacher Development Program to Enhance Learning Competency for Small Primary Schools in Thailand. Social and Behavioral Sciences, (Online), 69: 1052-1058, (http://www.sciencedirect.com), diakses 11 Mei 2017.

Kanokorn, S., Pongtorn, P., Sujanya, S. 2014. Soft Skills Development to Enhance Teachers' Competencies in Primary Schools. Social and Behavioral Sciences, (Online), 112: 842-846, (http://www.sciencedirect.com), diakses 11 Mei 2017.

Kemenag Jatim. 2010. Petunjuk Teknis Pelaksanaan Jabatan Fungsional Guru dan Angka Kreditnya, (Online), https://jatim.kemenag.go.id/files/jatim/file/file/peraturan tentangPNS/vsef1413864091.pdf, diakses 2 April 2017.

Kementerian Pendidikan Nasional Dirjen Peningkatan Mutu Pendidikan dan Tenaga Kependidikan (PMPTK). 2012. Buku 1 Pedoman Pengelolaan Pengembangan Keprofesian Berkelanjutan (PKB). Jakarta: Badan PSDMP dan PMP.

Koenen, A.K., Dochy, F., Berghmans, I. 2015. A phenomenographic analysis of the implementation of competence-based education in higher education. Teaching and Teacher Education, (Online), 50: 1-12, (http://www.sciencedirect.com), diakses 12 Mei 2017.

Korthagen, F., Loughran, J., Russell, T. 2006. Developing fundamental principles for teacher education programs and practices. Teaching and Teacher Education, (Online), 22 (8): 1020-1041, (http://www.sciencedirect.com), diakses 12 Mei 2017.

Korthagen, F.A.J. 2014. Promoting Core Reflection in Teacher Education: Deepening Professional Growth. Advances in Research on Teaching, (Online), 22 (1): 7389, (http://dx.doi.org/10.1108/S1479-3687201 400000 22007), diakses 7 Oktober 2016.

Leijen, Ä., Allas, R., Pedaste, M., Knezic, D., Marcos, J.J.M, Meijer, P., Husu, J., Krull, E., Toom, A. 2015. How to Support the Development of Teachers' Practical Knowledge: Comparing Different Conditions. Social and Behavioral Sciences, (Online), 191: 1205-1212, (http://www.sciencedirect.com), diakses 11 Mei 2017. 
Lin, H.C.K., Wu, C.H., Hsueh, Y.P. 2014. The influence of using affective tutoring system in accounting remedial instruction on learning performance and usability. Computers in Human Behavior, (Online), 41: 514-522, (http://www.sciencedirect.com), diakses 12 Mei 2017.

Moleong, L.J. 2014. Metodologi Penelitian Kualitatif. Bandung: Remaja Rosdakarya.

Nasongkhla, J. \& Sujiva, S. 2015. Teacher Competency Development: Teaching with Tablet Technology through Classroom Innovative Action Research (CIAR) Coaching Process. Social and Behavioral Sciences, (Online), 174: 992-999, (http://www.science direct.com), diakses 11 Mei 2017.

Peraturan Menteri Negara Pendayagunaan Aparatur Negara dan Reformasi Birokrasi No. 16 Tahun 2009 Tentang Jabatan Fungsional Guru dan Angka Kreditnya. Dinas Pendidikan Tarakan Kota. (Online), (http://disdik. Tarakankota.go.id /wpcontent/uploads/2013 /11/PERMENPAN 2009_016. pdf.), diakses 7 Oktober 2016.

Peraturan Pemerintah No. 19 Tahun 2005 tentang Standar Nasional Pendidikan. Koordinasi Perguruan Tinggi Swasta (Kopertis). (Online), (http://www.kopertis1.or.id/files/pp-19-tahun-2005-ttg-snp.pdf), diakses 20 September 2016.

Plessis, A.E.D. 2015. Effective education: Conceptualising the meaning of out-offield teaching practices for teachers, teacher quality and school leaders. International Journal of Educational Research, (Online), 72: 89-102, (http://www.science direct.com), diakses 11 Mei 2017.

Ramdhani, N., Ancok, D., Swasono, Y., Suryanto, P. 2012. Teacher Quality Improvement Program: Empowering Teachers to Increasing a Quality of Indonesian's Education. Social and Behavioral Sciences, (Online), 69: 18361841, (http://www.science direct.com), diakses 10 Mei 2017.

Rhoads, K. \& Weber, K. 2016. Exemplary high school mathematics teachers' reflections on teaching: A situated cognition perspective on content knowledge. International Journal of Educational Research, (Online), 78: 112, (http://www.sciencedirect.com), diakses 11 Mei 2017.

Rosenbluh, I.F. 2016. Behind the scenes of reflective practice in professional development: A glance into the ethical predicaments of secondary school teachers. Teaching and Teacher Education, (Online), 60: 1-11, (http://www.sciencedirect.com), diakses 12 Mei 2017.

Sales, A., Traver, J.A., García, R. 2011. Action research as a school-based strategy in intercultural professional development for teachers. Teaching and Teacher 
Education, (Online), 27 (5): 911-919, (http://www.sciencedirect.com), diakses 12 Mei 2017.

Salinan Peraturan Menteri Pendidikan Nasional No. 16 Tahun 2007 Tentang Standar Kualifikasi Akademik dan Kompetensi Guru. Kementerian Pendidikan dan Kebudayaan.(Online),(http://vervalsp.data.Kemdikbud .go.id/prosespembelajaran /file/Permendiknas\%20No\%2016\%20Tahun \%202007.pdf), diakses 20 September 2016.

Sellars, M. 2012. Teachers and Change: The Role of Reflective Practice. Social and Behavioral Sciences, (Online), 55:461-469, (http://www.sciencedirect.com), diakses 13 Mei 2017.

Sibley, E. , Theodorakakis, M., Walsh, M.E, Foley, C., Petrie, P., Raczek, A. 2017. The impact of comprehensive student support on teachers: Knowledge of the whole child, classroom practice, and Teacher Support. Teaching and Teacher Education, (Online), 65: 145-156, (http://www.sciencedirect.com), diakses 11 Mei 2017.

Sugiyono. 2015. Metode Penelitian Pendidikan Pendekatan Kuantitatif, Kualitatif, dan $R \& D$. Bandung: Alfabeta.

Ulfatin, N. 2013. Metode Penelitian Kualitatif Di Bidang Pendidikan: Teori dan Aplikasinya. Malang: Bayumedia Publishing.

Undang-Undang No. 14 Tahun 2005 Tentang Guru dan Dosen. Humas Universitas Negeri Medan. (Online), (http://humas.unimed.ac.id/wpcontent/uploads/2015/04/Undang-Undang-Nomor-14-Tahun-2005.pdf), diakses 20 September 2016.

Wiliam, D. 2011. What is assessment for learning? Studies in Educational Evaluation, (Online), 37 (1): 3-14, (http://www.sciencedirect.com), diakses 12 Mei 2017.

Wuryandini, E. 2014. Analisis Permasalahan Dan Kebutuhan Pengembangan Keprofesionalan Berkelanjutan Guru SMK BidangKeahlian Bisnis dan Manajemen Pasca Sertifikasi di Kota Kota Semarang. Jurnal Manajemen $\begin{array}{lllll}\text { Pendidikan, } & \text { (Online) } & 9 & \text { (2): } & 108\end{array}$ 119,(Journals.ums.ac.id/index.php/jmp/article/download/1692/1194), diakses pada 26 Februari 2017. 